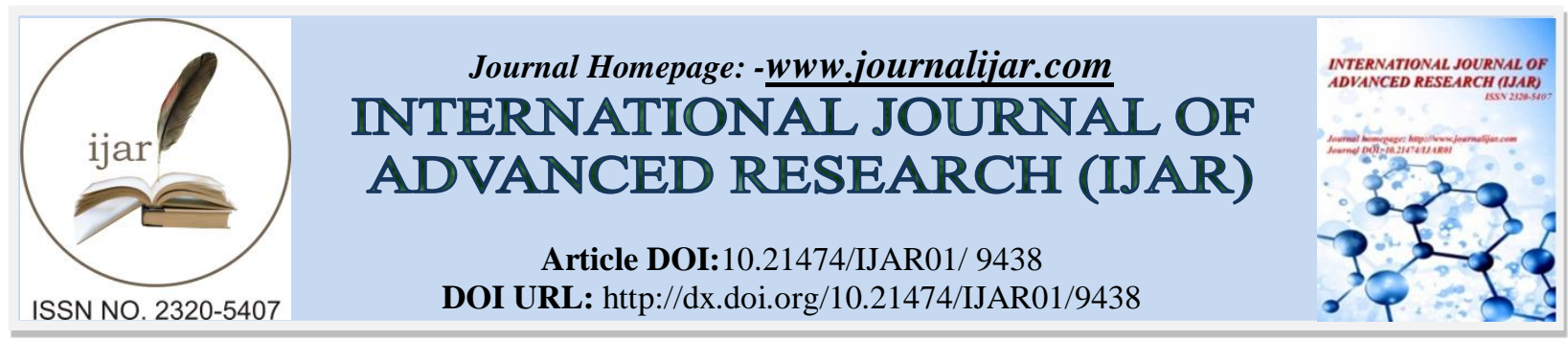

RESEARCH ARTICLE

\title{
CONTEMPORARY PROBLEMS OF HUMAN RESOURCE MANAGEMENT IN THE BULGARIAN HOTEL INDUSTRY.
}

Greta Hristeva.

\section{Manuscript Info}

Manuscript History

Received: 24 May 2019

Final Accepted: 26 June 2019

Published: July 2019

Key words:-

human factor, tourism, employees, new generation, hotel business

\begin{abstract}
The human factor in tourism is a fundamental aspect in achieving success in the respective company. In order for a business to be successful, a leading role is played by the quality of employees who serve clients, their qualifications, motivation, knowledge and willingness to work, learn and develop. In the $21^{\text {st }}$ century employers come face to face with the new generation and its peculiarities in perceiving the world. The present paper studies the real problems the bulgarian hotel industry face when approaching young employees in tourism.
\end{abstract}

Copy Right, IJAR, 2019,. All rights reserved.

\section{Introduction:-}

In the era of technology where mass communication is in the form of an exchange of text messages, voice messages, photos, statuses, gifs etc., the lack of real conversation is obvious. Technology is part of our every-day lives-we use it in our free time and at work. To a greater extent it facilitates and creates better working conditions in many firms and companies but in tourism the most important factor- the human one that presents the emotional aspect of the relationship between the client and the firm- cannot be displaced. The human is the real subject that is the driving force for the success of a certain tourist company in our contemporary and competitive world.

The human factor in tourism is not just one of the factors but probably the most important one in a tourist company. Employees are the "face" of the company, they establish the brand of a specific tourist company, they arouse consumer's emotions and participate directly in the creation and production of the tourist product- the very thing that differentiates tourism from other sectors. That is why the appropriate human resource management in tourism is so essential. When the employees of a specific company feel well, they have been acquainted with the company's principles, goals, conditions, when they feel as a part of the team, when they are motivated, they work wholeheartedly, they follow the internal rules and they develop a sense of belonging to the company, they do their work well, they smile (one of the most important things in tourism), therefore, the consumers of the tourist servicesthe clients- are satisfied which means success for the firm. When employees feel this way and perform their duties with willingness, motivation, joy, then the firm is competitive since in our contemporary world the client has infinite choices for destinations and conditions but what attracts him/her to a particular company is the attitude and behavior which he receives from employees.

\section{Contemporary conception of human resource management}

A parallel between the scientific achievements of the mid 20th century and contemporary achievements regarding the place and role of the human factor, the approaches and mechanisms of action on the people in the organizations, reveals the successful rationalization and development of this field with the leading idea of "recognition of the 
human as the most precious asset for each organization and, therefore, a potential bearer of the lasting competitive advantage of the organization"1

The contemporary conceptions for human resource management are based on and directed mainly at the managerial necessities of human resources which need to be provided and allocated in the most appropriate manner for the company $^{2}$. A strong emphasis is placed on long-term planning, supervision and control and the manner in which managers chose their organization to function in. Each managerial decision on human resources "derives from" this essence of the organization. Therefore, human resource management is completely ineffective in companies where managers and owners do not realize the true nature of the organization the attitude of the people within it. The idea that lies in the basis of human resource management is that the management of this resource is as important as the management of any other resource of the company and is an integral part of its management. Personnel being the company's valuable asset, have the right to appropriate treatment in the work process and would be much more efficient and useful for the company's prosperity if their professional career and their needs for qualification and development are satisfied. All of the above-mentioned should be achieved in the context of efficient management of the company's human potential and mutually respective work relationships.

We can describe the functions of the traditional human resource management departments in the following way ${ }^{3}$ :

1. Recruitment of new employees- the staff management departments announce the vacant positions and maintain contact with the labour offices;

2. Personnel selection- the personnel management departments collect and analyse documents and recommendations of the candidates and "sift out" the applications of candidates suitable for the positions in the company;

3. Remuneration - the role of the personnel management departments is insignificant but the departments deal with calculating salaries;

4. Performance assessment - personnel management departments coordinate managers' work in evaluating the individual achievements of their employees;

5. Training and development- personnel management departments coordinate training programmes;

6. Communications - personnel management departments provide information on the activities in the company in the form of company newspapers, newsletters, leaflets, videos;

7. Administration - personnel management departments maintain database about the staff.

The regulation of such relationships is quite commonly the starting point from which the activities on improving the working conditions, the personnel evaluation and work payment system, training and staff development are initiated. Considerable differences in the staff recruitment, qualifications, remuneration and training in the different kinds of companies in tourism industry exist. An especially substantial difference exists between seasonal tourist destinations and year-round ones. It is further aggravated by the difference between business hotels and restaurants in big cities and tourist destinations in the remote parts of the country.

Despite the theory which gives numerous directions on the appropriate human resource selection, employment, training and management in a particular company, the business faces considerable difficulties in the recruitment in this field nowadays. The human capital flight outside the country does not leave Bulgarian employers with a great variety of human resource.

\section{Research analysis:-}

For the purposes of the present study and to identify the problems in human resource management in the Bulgarian hotel business, a survey in the form of an interview with managers of seaside, city and winter hotel complexes of different categories was conducted. The interviews were carried out as free talks in which the leading topic was the pressing issue of the human factor in the business in the face of the young generation.

\footnotetext{
${ }^{1}$ Yosiv Iliev, Human Resource Management- the Necessary Transition from Science to Practice of Bulgarian Companies.

${ }^{2}$ Chaushev, A. Personnel Management. University Publishing House "Stopanstvo", Sofia, 1999, p. 6.

3 Thomason, G., The Manager ofr Personel: The Management of Human Resources: Selected Readings, Management Decision, 1992, Vol. 30, Nr. 6, p. 11.
} 
Following the conducted survey among Bulgarian managers of hotel complexes, it is apparent that the hotel business suffers from the lack of well qualified staff for the positions of reception administrator, chef, waiter, barman, hotel maid. These are the positions in which the lack of employees impedes the successful presentation of the tourist product.

Managers share the opinion that it is difficult to find good employees who meet the requirements for a certain post among the young Bulgarian sitizens. They implement changes in the internal organization in order to satisfy the demand on the side of young candidates for work but meet people who "want high salaries, more free time, higher posts but do not have enough experience and a definite value which to provide to the firm and defend their conditions" - these are the words of one of the managers who summarizes the situation with employees in tourism. It is the generation $\mathrm{Y}$ that we are discussing here- they are also called "millennials" which in Bulgaria is more pronounced due to the small number of the population and young people's migration. Simon Sinek explains the behavior of this type of employees in the following way: "It is about a unique behavior of millenials at the workplace. Many employers complain that their employees have problems with communication, do not have the attitude to be active, do not tolerate criticism, they are impatient and incapable of committing. And the most serious remark- they behave as if the whole world owes them something."4

Low salaries in tourism are a serious factor for the lack of candidates in the sector but "it is difficult to raise the salaries when there is no basis on which to stand- young candidates do not have basic knowledge, they don't know foreign languages and when we talk about seasonal jobs we don't have enough time to spare for training."

This forces managers to look for work force outside the country's borders. In the last few years it is quite common for managers to hire seasonal workers from Ukraine and Moldova. According to the data, up to March 2019, more than 7800 workers from foreign countries were registered and they occupy key posts in the hotel complexes for the summer season. When asked whether a foreign employee manages better with his/her duties and whether it is financially better for the company, I can summarize the answers in the following manner: from a purely financial point of view a foreign employer requires more costs from the company because the expenses are higher- transport, documents, accommodation (it is common for Bulgarian employees to have their own place to stay). Ukrainians and Moldovans do not have requirements on the payment and have higher motivation for work and training, probably because they still appreciate the opportunity which is given to them- to work, to be at the seaside, to earn enough according to their standards (as is the situation with Bulgarians working abroad). Some hotels have officially introduced job descriptions which are signed by the newly employed and thus they are acquainted with the specificity of their work and the responsibilities they have in their job. This helps managers organize their overall work more easily, to communicate with their employees more fluently and at the end of the work day - if there are any problems- where they can be identified. To foreign employees this is also the best solution since they know what is expected of them and they can perform their duties more calmly. As we have already clarified- when the employee feels well and is calm, his/her work is better and this means positive results for the business but also for the client who comes first.

When managers were asked the question "What needs to change and where the problem with personnel stems from?", I can say the answers included training, regarding not the theoretical part with which "everybody can google the information he/she needs" but the practical training which includes solving various problems, the development of abstract reasoning beyond the norm in order to cope with problems in extreme situations since tourism is a field where you work with people with their own individual needs, wishes, points of view etc. emergency situations are more common than in any other field of work. Another example for the change mentioned in the interviews was to build up and instill work ethic in young people, to establish stricter rules at universities where tourism specialists are trained, to give more out-of-class assignments and to establish stricter control on performed activities. They think that one of the problems of the youth's psychological attitude is namely the perceived idea that no matter they do, they will finally have an excellent assessment. "This plays a practical joke on them because it creates a sense of grandeur which impedes their development and detains us as employers to hire responsible people whom we can rely on."-these are the words of a manger of one of the leading hotel complexes on the Black Sea coast.

According to official data, there has been a decline in the number of tourists in June 2019- many of the hotels are empty and reservations are lacking even for the busiest month of the season- August. The true cause lies not in the

\footnotetext{
${ }^{4}$ Sinek S., Leaders Eat Last, “Krugozor” Publishing House, Sofia, 2018
} 
high prices but in the long years of bad service in our country. The tourist is willing to pay a higher price, to stay in the same hotel every year, to accept the lower quality of food if he/she has come across positive attitude in the people who serve him. The lack of qualified staff in Bulgaria is mainly due to the fact that our young people do not have the willingness and motivation to learn, do not have the motivation to work, do not have the sense of belonging to a company which is the cause for the turnover of staff especially in the seasonal work.

Despite the fact that the lack of qualified young people is considered the biggest problem, hotel managers also make mistakes in human resource management. Hotel managers are aware of the theory of hotel management, restaurant management, and human resource but in practice, in many situations they have to fluctuate between theory and real problem. Above all, managers need to be leaders and not just managers in order to cope with the new staff. They also need to adjust gradually to the "new trends" among young employees and motivate their staff through different methods so that their final result is a successful season.

There are several steps approved by experts in international consultant companies for employee retention which would be useful in human resource management in the hotel business with young staff ${ }^{5}$ :

1. Opportunity for professional development- the awareness on the side of employees that they have the opportunity for a professional career, the clearly-defined steps which must be taken in order for them to develop would provide employers with staff who would not leave their workplace.

2. Meaningful work and goals - it is important that employees are aware of their responsibilities and duties because that would give them confidence in their abilities and they would know what to do.

3. Recognition and awards - apart from salaries, employees need to be recognized and awarded additionally when they do their work well. Monthly bonuses, discount vouchers, shopping vouchers, holidays, team building etc. would motivate staff to do their best at work.

4. Evaluation and recognition of achievements- studies have shown that the frequent recognition of achievements is an efficient nonmonetary incentive and motivator.

Making use of these several guidelines for employee retention is a possibility for coping with staff turnover. Thoughtfulness, respect for personal space, frequent communication on the side of managers with their employees in an informal setting in order to develop and integrate "millennials" in the tourist company can be added to the abovementioned steps.

\section{Conclusions:-}

The human factor in the hotel business is the basis for a successful tourism. Without the qualified staff hotels cannot function, therefore, managers' efforts should be directed at understanding generation Y, creating appropriate working conditions, in which a leading role should be played by the building of employee's motivation and creating a sense of belonging to the respective company. Even if we do not think that the problem of lack of staff is in human resource management in the hotel business, but in the overall psychological change in the generation, hotel owners face the difficult tasks of changing their policy, elaborating on new strategies and programmes and adapt to the labour market and not the opposite so that hotel complexes can function properly since employers are dependent on staff in the sphere of tourism.

\footnotetext{
${ }^{5}$ Pencheva,A., Instruments for Human Resource Career Management in Tourism. Tourism in the Age of Transformation, Proceedings from the International Scientific Conferece, "Naouka and Ikonomika" Publishing house, University of Economy-Varna, 2015.
} 